\title{
Aldosterone Receptor Antagonist
}

National Cancer Institute

\section{Source}

National Cancer Institute. Aldosterone Receptor Antagonist. NCI Thesaurus. Code C101255.

A class of agents that act by selectively inhibiting aldosterone receptor activation with diuretic activity. Aldosterone receptor antagonists bind to and block the activation of aldosterone (mineralocorticoid) receptors on the epithelial cells in the late distal tubule and collecting duct of the kidney, thus preventing the synthesis of aldosterone-induced proteins which enhance $\mathrm{Na}+$ retention and $\mathrm{K}+$ and $\mathrm{H}+$ secretion. The enhanced excretion of $\mathrm{Na}+$ produces diuresis ultimately resulting in a reduction in blood pressure without the loss of $\mathrm{K}+$. 